\title{
International Criminal Law and Extradition of Persons with Penal Responsibility. Albanian Experience
}

\author{
Nikolin Hasani \\ Ph.D student at Faculty of Justice \\ University of Tirana, Albania \\ hasani.nikolin@yahoo.com \\ Ulvin Veizaj \\ University of Vlora "Ismail Qemali", Albania \\ Faculty of Human Sciences, Department of Justice \\ veizajulvin@yahoo.com
}

\section{Doi:10.5901/ajis.2013.v2n8p747}

\begin{abstract}
While the borders are open and the world has become more global even for Albanians, there are created some conditions which favorite some citizens who commit crimes in one country and flee to another country to escape facing justice and deserved punishment. To serve such a purpose in 1923 was created the International Criminal Police Organization, known as "Interpol". This institution has branches in all countries that have signed agreements of international criminal cooperation, as well as Interpol Tirana. These are bodies that help in different ways the extradition of wanted persons. The purpose of this paper is to give an overview on extradition procedures and the way it is fixed by international and national laws. The paper will start with the specific rules for the person extraditions in both cases: when the person is required to be transferred from outside and when the person is required to be transferred from inside out. Then a special analyze will be made to cases when extradition is possible as well as cases when extradition may be refused due to legal provisions or procedural violations. To present the Albanian experience in person's extradition, some specific cases in which the extradition is rejected will be analyzed, giving the reasons of this rejection. At the end, the authors are giving some recommendations on how to have a more efficient extradition process in Albania.
\end{abstract}

Keywords: extradition procedures, penal responsibility, international criminal law

\section{The Legal Basis and Conditions for Extradition in Albania}

The opening of borders in Albania since 1991, created the possibility of movement of Albanians to others countries and foreigners to our country. The most common reasons of these movements for Albanians varied from tourism to work. The same can be said for foreigners who have come in Albania during this period. Besides the positive sides, this movement has been followed by negative consequences, particularly in the area of crime. Now is a known fact and a more widespread opinion that Albania is a country with relatively high level of criminality. Every day in the media channels and police press release are given information about criminal nature events, which are espied by investigators who start the criminal proceedings, to carry out further investigation actions and to collect and administrate the evidences for these cases. This is the moment in which perpetrators should be given legal responsibilities, and this does not excluded the cases in which persons commit an offense in one country move to another country in order to evade justice taking advantage of the principle of territorial sovereignty of countries. Given this reality, international cooperation in criminal matters become necessary. In the absence of such cooperation between states a large number of offenders who leave the country where they have committed the crime, can not be condemned as repressive power of the state lies only within its territorial boundaries. Therefore the integrating developments in global processes must also bring an intensive development of judicial cooperation instruments, raising it to a higher level in order to make it more effective.

Catching of perpetrators and confronting them with justice bodies it is done in different ways. It is easier to work with the following categories of persons caught in the act of crime by the police, as well as those who surrender themselves to the police. A third category consists of those who are identified later. After the examination and expertise of traces has be done, capture of these persons can be done at home or in other places frequented by them. But there is 
another category that after committing the crime manage to flee abroad, to hide the traces of the crime and to escape confrontation with the investigation. Even for these offenders, law enforcement authorities examine evidence collected at the scene and, following an investigation, after reaching the conclusion that it is done correct identification of the author or authors of the offense, make announcement on national and international research, to capture them, in view of the investigation, trial and sentencing.

When there are evidence that these persons are abroad, then the activation of police services in other countries is requested. To ensure the complete identification of the person and the transmission of necessary documents, these law enforcement authorities coordinate with each other through Interpol, in order to realize the extradition of persons to the country that has declared them wanted. To have clarity regarding the procedures and bodies involved in this activity, we should do some preliminary definitions dealing with international legal relations and institutions.

Based on Article 10 of the Criminal Code Procedure, legal relations with foreign authorities mean the relationship created between states according to international agreements, bilateral or multilateral, on the basis of recognized principles and norms of international law and the provisions of the Criminal Code Procedure, in order to have an international cooperation in criminal matters. From the above definition it follows that these relationships are based on the norms of international law and the norms of domestic law of each country. Specifically Albanian state has ratified a number of multilateral agreements, which have the major share of conventions within the Council of Europe and their additional protocols, which regulate legal relations with foreign authorities. The following can be mentioned as the most important:

- Convention "On Extradition" and its two Optional Protocols, ratified on 02.04.1998.

o Convention "On the transfer of proceedings in criminal matters", ratified on 10.06.1999.

- Convention "On mutual legal assistance in criminal matters" and its Additional Protocol, ratified on 10.06.1999.

- Convention "On the Transfer of Sentenced Persons", ratified on 10.06.1999.

Mutual legal assistance consists of acts carried out by a state appointed under the Criminal Code and international cooperation aimed at assisting the development of criminal proceedings being conducted in another state to the author of an offense. All these actions are carried out in view of extradition of persons. Extradition is a legal action that is realized in the framework of international cooperation, according to which a given state submits a person found in its territory a requesting country, where he is suspected to have committed a crime, in order to enable the investigation, trial or suffering of a conviction by the court ${ }^{1}$. By this definition means that extradition is made for three main purposes:

- The transfer of persons against whom criminal case was started in the state where he is considered a wanted person,

- To implement a security measure, according to the decision of the judicial authority of the requesting state,

- For executing a penalty final decision, provided by the requesting state.

By this definition it is meant that the state to which is requested a person found in its territory, give him back to the state which made the request for extradition². The legal basis were extradition is based, as a legal procedural action consists of:

- Interpol's Constitution,

- Criminal Procedure Code of the Republic of Albania,

- Bilateral international law, according to the model developed by the UN,

- Multilateral conventions, such as the European Convention on Extradition,

- Basic documents Interpol as general regulation, financial regulation, etc..

The extradition of wanted persons is of two kinds, because there are two directions of movement of people who are associated with the underworld. Extradition is inactive when a person wanted by a state is inferred outside Albania, and is active when a person is brought in Albania, where he is suspected of committing a crime. In the Constitution of the Republic of Albania, Article 39/2 is sanctioned that extradition may be allowed only when it is provided in international an agreements to which Albania is a party, and only if there is a court decision.

\section{International Extradition Institutions}

Announcement on international search and then the search for persons who become subject to extradition, is carry out by

${ }^{1}$ European Convent on extradition, 1957.

${ }^{2}$ Penal Procedure Code of Republic of Albania, article 488, page 243, year 2004 
the International Criminal Police Organization, known mostly by the name of INTERPOL. Interpol was created by the Congress of Vienna in 1923 and its center is in Lyon, France. In the international police organization are members only those states that have accepted and subsequently ratified by law constitution of Interpol.

The scope of Interpol is directly related to issues of special importance, such as public safety and terrorism, criminal organizations, drug related crimes, high-tech crimes, financial crimes, trafficking in human beings. Interpol also deals with the support of investigative procedures in the field of the fight against crime. One of its tasks is to provide its members with the list of the names and information about the persons wanted by international police force. For example, if Interpol is looking for a particular trafficker, police member has a legal obligation to register it in the list of persons wanted by Interpol. This means that the tracking and arresting the wanted person is the responsibility of the state where he is staying. In such cases, Interpol support police action by information exchange, creating convenience for cooperation and coordination of actions among member countries. It provides assistance to all police authorities and other institutions have a legal obligation to cooperate in the prevention and fight against crime ${ }^{3}$. In this process, all these institutions operate within the framework of the "Universal Declaration of Human Rights".

\section{Tirana Interpol}

Interpol's institutional structure is wide enough due to the fact that its offices are located in the territories of all member states, also in our country. National Central Bureau Interpol Tirana is a special structure in the General Directorate of State Police, responsible for relations with the central structures and the Interpol National Central Bureaus counterpart. It implements the service standards of a National Central Office ${ }^{4}$. Its activity also takes place in accordance with:

- Constitution of the Republic of Albania;

- Interpol's Constitution, the law "On accession of the Republic of Albania in the International Criminal Police Organization Interpol"5;

- National criminal legislation ${ }^{6}$ and criminal procedure ${ }^{7}$;

- Law "On the State Police"8

○ Every international agreement ${ }^{9}$ to which Albania is a party.

The following basic Interpol documents serve as legal basis on which the National Central Bureau (NCB) of Tirana Interpol is based for its activity: general rules, financial regulations, operation standards of head national offices and regulation on international cooperation and control of Interpol archives. These documents are required to be implemented by each state. However, in the case of provisional arrest with a view to extradition of a citizen of our country from an NCB counterpart, Interpol Tirana, upon notice, cooperates with the Ministry of Justice and the Attorney General to send the necessary documents for the extradition of citizen. This documentation is forwarded through diplomatic channels, respecting the time limit provided in the Convention ${ }^{10}$ or bilateral agreements.

In cases where an Albanian citizen has committed a crime out of our country and is declared wanted by an NCB international counterparts, while the citizens is in the territory of the Republic of Albania, Tirana Interpol, upon notice, inform and cooperate with central and local structures of our State Police to identify its location. Then it notifies the competent Ministry of Justice and the Prosecutor General. Whereas in cases where the person is a foreigner, especially Albanian citizen who has acquired citizenship in a foreign country, and international research announcement is made from one of the countries with which we have bilateral extradition agreement, the person is arrested to be extradited to the requesting country. At the same time, National Central Bureau of the state which requires the person to be arrested in order to extradite him is informed and them is proceed with the delivery of the documents by diplomatic channels, through our Ministry of Justice, within a 40 day period ${ }^{11}$.

\footnotetext{
3 Interpol Constitution, year 1956, article 2, 1 \& 2, page 1.

${ }^{4}$ Approved by 33Europian Regional Conference for Interpol, Kiev, May 12-14, 2004.

5 Law nr. 8427, December 14. "For the adhere of the Republic of Albania in Interpol".

${ }^{6}$ Penal Code of Republic of Albania, approved by the Law nr. 7895, January 27.1995, changed by the Law nr. 9188, February $12,2004$.

${ }^{7}$ Penal Procedure Code of Republic of Albania, approved by the Law 7905, March 21,1995, changed.

${ }^{8}$ Law nr. 9749, June 04.2007, "For State Police".

${ }^{9}$ Approved by the Law nr. 10193, December 03.2009 "For jurisdictional relations with foreign authorities in criminal matters".

${ }^{10}$ Article 16, European Convention on extradition.

${ }^{11}$ Article 27, Law nr. 8778, January 26,2011 "For the ratification of Penal convention for Corruption", updated by the Law nr. 9369, April 14,2005.
} 
Based on our Constitution and the Criminal Procedure Code of the Republic of Albania, extradition is possible only if approved by the court. In this case the Ministry of Justice shall send the relevant documentation to the requesting country, which should definitely include the court along with an order for enforcement of Interpol Tirana, within the time limiti2. Extradition shall be granted only when it is expressly provided for in the international agreements to which Albania is a party and when there is a court decision ${ }^{13}$.

In the case when our law enforcement bodies seek for the extradition of a person prosecuted or convicted in a foreign country, to whom must be executed a measure that restricts his personal freedom, is the Ministry of Justice which has the competence to perform this procedure. To achieve this goal, court prosecutor, in whose territory it is processed or rendered the sentence, made a request to the Ministry of Justice, sending it the necessary acts ${ }^{14 "}$.

\section{Extradition Procedures}

When extradition of a person from abroad is required, is the Ministry of Justice that has full authority to request to a foreign country for extradition of a person prosecuted or convicted, to whom should be sung a penalty measure, which restricts his personal freedom. Before the police begin to work for the international research of a Albanian citizen or a foreign citizen, or a stateless person who has committed a crime within the territory of our country, first they should start with the opening of "overseas research record". Then, at the request of the central or local police or judiciary, when there are available evidence that the person is abroad, the person is declared wanted internationally. The request for extradition is presented in a written form and is forwarded through diplomatic way. This means that the application should be submitted through the Ministry of Foreign Affairs ${ }^{15}$ and must be based on information received from the Prosecutor General. The application must be accompanied by some additional documents required, as follows:

- Original or certified copy of the decision formalized as a final sentence, and the order of arrest or any other act that has the same active force, issued in accordance with the laws of the requesting party.

- List of the the facts upon which supports the request for extradition, such as the time and place of the offense, its legal definition, references to relevant legal provisions that apply in such cases and a complete report on the procedural acts basis of which the person is identified as the author of the event.

- A more accurate description of the individual features required and any information that can be used to determine his identity and citizenship. This includes the evidence which fully identify the person, such as photographs, passport card, fingerprint records, fingerprints etc. ${ }^{16}$.

In cases where both countries have certain direct agreement between them, they can act as procedural specifications set out in these agreements. But despite the concrete path to be followed in a particular case extradition, the requesting state should be party to the agreement in the context of the European Convention and its two protocols.

When it is needed the extradition of a person from other countries, the request is presented to the Ministry of Justice, which, in the case of approval, forward the documents to the prosecutor of relevant court. After reviewing the documentation within three months prosecutor submits to the court a request for review.

The person for whom the extradition is request, based on the request of the Ministry of Justice, prosecutor may order coercive measure and set the seizure of material evidence related to the criminal offense. According to the Article 495 of the Code of Criminal Procedure, in urgent cases, judicial police can make arrests of the person against whom is requested temporary arrest.

When there is implemented an austerity coercive measure, the court no later than five days after the execution of the measure or its assessment, provide the identity of the person and his possible consent.

The court decides in favor of extradition when there are relevant evidences on culpability or when there is a final sentence. The court decides not to extradite a person when there is the case of non-extradition. After the decision is given by the court, is the Ministry of Justice that has the power to make the final decision whether or not the request for

\footnotetext{
12 Regulation nr. 759, May 21, 2008 "For the functioning of National Center Office Interpol Tirana", pg. 22., according to the European convent for extradition.

${ }^{13}$ Constitute of Republic of Albania, article 9, page 7.

${ }^{14}$ Penal Procedure Code, article 504, page 252.

15 Penal Procedure Code of Republic of Albania, approved by the Law nr. 7905, March 21, 1995, changed by the Law nr. 9276 , September 16, 2004.

${ }^{16}$ The interpretation is found in the Penal Procedure Code of Republic of Albania, Article 489, which refers to the European Convent for Extradition, year 1957, article 12, pg. 5.
} 
extradition will be accepted. Extradition decision losses power when, and the detainee is released, when requesting state does not act within the time specified for receipt of the extradition. Execution is suspended when the extradition person should be tried in the territory of Albanian State, or must serve a sentence for offenses committed before or after the offense for which is decided extradition.

Legal procedures for extradition implementation are very complicated. They are designed in such a way as to ensure the transfer of an accused to the jurisdiction of a country under the jurisdiction of another country. But these procedures should not be confused with the mutual legal provisions relating to the evidence obtain.

But legal provisions for extradition of a citizen from a country's jurisdiction to that of another country can vary greatly depending on the nationality of the person who is requested to be extradited, on the country or countries concerned by this person, and on the type a criminal offense that may have committed. These actions can be more subtle when in the extradition issue intervene certain political point of view or principles, especially in the case of a possible capital punishment.

The requests for extradition or enforcement decisions should be reviewed and managed by specialized lawyers, located near the respective ministries. The main condition remains the obligation that the requesting state should be part of the multilateral agreement in the framework of the European Convention on Extradition or bilateral agreements. While the "golden rule" that should be followed is to establish contacts with relevant legal department within the right ministry and carry out their advice and instructions ${ }^{17}$.

\section{Cases of Extradition Refuse, Albanian Experience}

Taking in consideration the police practices in different European countries in recent years regarding the procedures for the extradition of the person, it is noted that authorities are often confronted with facts such as: request for extradition from several states at once for the same person, with refusal of extradition for reasons related to the lack of documentation or other unforeseen reasons. If the requests for extradition of a person are refused by the countries where he is been arrested him because the serious charges, then the consequences will fall upon the requesting state, damaging all initiated criminal proceedings.

In cases where there is competition for extradition requests, which means that the extradition of a certain person also required by some states, it is the party to which have been addressed the request for extradition who decides. In its decision the party should take into account all the circumstances, particularly the fact that which of the offenses it is considered most serious, it should also take into account the place of the offense, the dates of request for extradition submission, citizenship of the person required to be extradition and the possibility of its further extradition to another state $^{18}$.

In many cases, for the persons who are subject to criminal responsibility, extradition can not be accepted by the country to which it is made the request for extradition. Such a possibility should be considered in all cases where extradition it is requested. What circumstances can serve as potential causes for rejection request, should be taken in consideration in advance in order to take all measures to prevent them. For example, one of the reasons for rejection may be the case when the prescription of the act or punishment, enters into force by the legislation of the two countries, the one which has requested the extradition and that to which requests for extradition have been addressed ${ }^{19}$.

The extradition is refused in the cases when for the offense, due to which the extradition is requested, based on the law of the country which make the request for extradition it is required capital punishment and based on the law of the country to which it is made the request for extradition such a punishment it is not applied. But extradition can be admitted to be conditional, in order that the requesting country guaranty that there will not be any capital punishment.

Such a case is the refusal of extradition request made from Interpol Beijing to the Albanian authority, regarding the extradition of five Chinese citizens, originating from Uighur tribes, who where accepted in the Albanian Asylum Centre. The refuse of the Chinese request for extradition where made because according to the Chine law the punishment for the offense which these persons where accused is death penalty, and if they were extradited to China, they were executed. The rejection of the request from the Albanian side was based not only on fundamental international documents relating to extradition, such as the European Convention on Extradition, and the Rome Statute of Interpol's Constitution, but also

\footnotetext{
${ }^{17}$ Dr. Hasan Shkëmbi, "Internationa collaboration", Tiranë, Albania 2006

${ }^{18}$ According to the European Convent for Extradition.

${ }^{19}$ This Fact is interpreted even in the Penal Procedure Code.
} 
in our domestic legislation, such as the Penal Code and Penal Criminal Code. The right of the Albanian derives from the "Universal Declaration of Human Rights", which our country has ratified by law20.

One of the cases where extradition is refuse is the case when the country to which is made the request for extradition evaluates the requests for extradition as politically motivated or consider the arguments of this request as related to a political reason ${ }^{21}$. As an example of such a case we can mention the refusal of extradition request made from Albania to the Belgium and Switzerland, for the members of the criminal organization "Revenge of justice"22. The argument for refusing extradition of these persons, from the Belgium and Switzerland authorities was the fact that their families origins connected with several high political officials of the communist regime in Albania and the mention of their names in political debates by various members, inside and outside parliament. The defense presented offenders as victims of a fierce political struggle, where extradition would bring them political persecution. Thus the measure of punishment given to the Albanian court was not taken into consideration even though there were convincing evidences that they were the authors of serious crimes.

The same rule applies when the country to which it is make the request for extradition believe that the real reason for extradition of someone is the race, religion, nationality and political opinion of the person ${ }^{23}$.

\section{The Consequences of Delays in the Exchange of Documents}

According to the opinions of specialists of Interpol, the procedure for extradition of wanted persons there are significant delays in the practice of exchanging documents between the respective ministries of homologous countries. Some countries, such as Australia, England and the Netherlands are punctilios deadline for documentation forward. They even require detail regarding the identification of the person, event, collected evidences.

Extreme delays in sending documents to fully identify the person especially noticed in the case of Albanian citizens that are arrested abroad. Local police authorities often send these documents outside the legal deadline of forty days. So it often happens that the person extradited does not have any valid identification for moving from one state to another. This fact makes the transit through airports difficult ${ }^{24}$.

Special difficulties are faced in the case of extradition of persons which are been convicted in absentia, especially for those who are arrested to be extradited from United Kingdom. This is because the authorities require convincing guarantee that after the extradition, the person will be retried. They justify this attitude with the concern that the principal of human rights are violated. The great difficulty lies in the known fact that police authority which execute the transfer of the person does not have the legal right to give such a guarantee 25 .

\section{Conclusions and Recommendations}

From the analyze of the process and procedures of extradition of persons we can conclude as follow:

1. Documents drawn up in accordance with the requirements of international conventions is a prerequisite for the successful extradition of persons. If documentation will present shortcomings, the person subject to extradition, makes it easier to present an alibi or to gain asylum.

2. If the documentation for a correct identification of the person wanted is not submitted within the legal limits, extradition may fail because the state in which the person is been arrested can not keep the person detained more than forty days and immediately performs his release.

3. Lack of bilateral agreements on extradition and mutual understanding between our country and some other countries, such as Greece, Belgium and the UK, is used by some Albanian citizens to shelter in Albania, after the commission of the crime in those countries, in order to avoid extradition.

Therefore, in order to improve the legal and institutional framework of the process of extradition of persons, should

\footnotetext{
20 Interpretation according the Penal Procedure Code of Republic of Albania.

${ }^{21}$. Based on the Convent, the murder of a person or attempted to murder the head of the state or any of the members of his family, are not considered political action. This is the only limitation posses by this convent for what is consider offense. In all other cases is up to the state to which it is requested the extradition, to decide if there is a political action or not.

${ }^{22}$ Information is taken from counter terrorism sector General Directory of Police.

${ }^{23}$ European Convent on Extradition, year 1957, articles 10 and 11, pg. 4.

${ }^{24}$ This fact was presented from the interview of a specialist of National Headquarter of Tirana Interpol.

${ }^{25}$ According to the interview of the officer of the Interior Minister of the United Kingdom.
} 
be taken into consideration some recommendations:

1. To extend institutional cooperation between the Ministry of Justice and Ministry of Foreign Affairs and counterpart ministries of other countries, in terms of the correct completion of documentation and accelerating the transferring procedures to their respective destination.

2. The police departments should make greater efforts in order to respect deadlines for person identification procedures, because any delay causes limit exceeding which leads to the release of the prisoner.

3. Bilateral agreements should be signed with some countries, such as Belgium, France, Greece etc.., in order to extradite Albanian citizens who have commit crimes abroad and currently are billeted in Albania, because of the lack of these agreements is was no extradition from Albania in these countries.

\section{References}

"Interpol: Albania is the first country in the world to demand", published by Ornela Manjani, in the "Balkans", dated 15.07.2009.

Annual Report 2009, 2010, 2011, the Interpol - Tirana.

Criminal Code of the Republic of Albania, approved by Law no. 7895, dated 27.01.1995, as amended by Law no. 9188, dated 12.02.2004 and added by Law no. 10023 dated 27.11.2008

Criminal Procedure Code of the Republic of Albania, approved by Law no. 7905, dated 21.03.1995, as amended by Law no. 9276, dated 16.09.2004

Dr.. Hasan Rock. International cooperation. Tirana, 2006.

European Convent on extradition, 1957.

European Convention on Extradition.

Interpol basic documents: General Regulation, - Standards functioning national headquarters, Regulation "On international cooperation and control of Interpol's archives."

Penal Procedure Code of Republic of Albania, article 504, pg. 252.

Penal Procedure Code of Republic of Albania, article 488, pg. 243, year 2004

Penal Procedure Code of Republic of Albania, approved by the Law nr. 7905, March 21, 1995, changed .

Penal Procedure Code of Republic of Albania, approved by the Law nr. 7905, March 21, 1995, changed with the Law nr. 9276 , September 16, 2004.

Penal Code of Republic of Albania, approved by the Law nr. 7895, January 27, 1995, changed by the Law nr. 9188, February 12, 2004.

European Convent on Extradition, year 1957, articles 10 and 11, pg. 4.

Constitute of Republic of Albania, article 39, pg. 7.

Constitute of Interpol, year 1956, article 2, pg. 1.

Law no. 10193, dated 03.12.2009 "On jurisdictional relations with foreign authorities in criminal matters".

Law no. 8322, dated 02.04.1998 "On ratification of the Council of Europe Convention on Extradition and the two Additional Protocols."

Law no. 8427, dated 14.12.1998 "On the accession of the Republic of Albania in the International Criminal Police Organization INTERPOL".

Law no. 8778, dated 26.01.2011 "On ratification of the Criminal Law Convention on Corruption", the date the law no. 9369, dated 14.04.2005.

Law no. 9871, dated 11.02.2008 "On ratification of the Agreement between the Republic of Albania and the Republic of Italy, in addition to the European Convention on Extradition of 13 December 1957 and the European Convention on Legal Assistance in Criminal Matters of 20 April 1959, which aims facilitate their implementation. "

Law nr. 8427, December 14, 1998 "Republic of Albania Accession in Interpol".

Law nr. 9749, June 04, 2007, "For State Police".

Article 16 of European Convent for Extradition.

Article 27, Law nr. 8778, January 26, 2011 "For the ratification of the Penal Convent for Corruption", updated by the Law nr. 9369, April 14, 2005.

Regulation no. 759, dated 21.05.2008 "On the functioning of the National Central Bureau - Interpol Tirana".

Regulation nr. 759, May 21, 2008 "For function of Central office of Tirana Interpol", pg. 22., according to the European Convent for Extradition.

Shkëmbi, H. 2006. "International collaboration"

According to the European Convent on Extradition.

The Constitution of the Republic of Albania.

The Rome Statute, signed by the Republic of Albania on July 18, 1998, ratified by Parliament by law no. 8984, dated 23.12.2002. 